\title{
Citizens, Knowledge, and the Information Environment
}

\author{
Jennifer Jerit University of Connecticut \\ Jason Barabas Harvard University \\ Toby Bolsen Northwestern University
}

\begin{abstract}
In a democracy, knowledge is power. Research explaining the determinants of knowledge focuses on unchanging demographic and socioeconomic characteristics. This study combines data on the public's knowledge of nearly 50 political issues with media coverage of those topics. In a two-part analysis, we demonstrate how education, the strongest and most consistent predictor of political knowledge, has a more nuanced connection to learning than is commonly recognized. Sometimes education is positively related to knowledge. In other instances its effect is negligible. A substantial part of the variation in the education-knowledge relationship is due to the amount of information available in the mass media. This study is among the first to distinguish the short-term, aggregate-level influences on political knowledge from the largely static individual-level predictors and to empirically demonstrate the importance of the information environment.
\end{abstract}

I: $s$ there a permanent information underclass in the United States? Decades of research would seem to suggest so. A voluminous literature shows that socioeconomic factors, such as being rich or educated, are positively associated with political knowledge (e.g., Bennett 1988; Delli Carpini and Keeter 1996; Neuman 1986). So well developed is this literature that the characteristics commonly associated with political knowledge are referred to as the "usual suspects" (e.g., Delli Carpini and Keeter 1996, 179). However, the focus on individual-level factors gives the impression of a static relationship between socioeconomic status and political awareness. Not only is this a normatively unsatisfying position, but it also strikes us as inaccurate. Citizens experience politics in an environment that changes over time as domestic and foreign developments unfold. In addition to individual-level characteristics, variation in the information environment likely has an influence on political knowledge.

Determining the nature of this influence has important implications for representative democracy. The uneven distribution of political knowledge biases the shape of collective opinion (Althaus 2003). Not only does political knowledge help citizens form stable, consistent opinions, but it also enables them to translate their opinions into meaningful forms of political participation (Delli Carpini and Keeter 1996). If variations in media coverage do little to offset the information advantage associated with high socioeconomic status, then large segments of the population will remain on the periphery of the American political system. If, on the other hand, the information environment can reduce the differences in political knowledge that exist between certain elements of society, there is hope that traditionally disadvantaged groups, such as the uneducated or the poor, can make their voices heard.

Our study investigates this issue by analyzing over three dozen public opinion surveys for a period of more than 10 years. In a two-part analysis, we examine whether differences in the quantity of media coverage alter the relationship between individual-level predictors, such as

Jennifer Jerit is a Fellow at the Roper Center for Public Opinion Research at the University of Connecticut and assistant professor of political science (on leave), Southern Illinois University, Carbondale, IL 62901-4501 (jerit@siu.edu). Jason Barabas is Robert Wood Johnson Scholar in Health Policy Research, Center for Government and International Studies, Harvard University, 1730 Cambridge Street, Cambridge, MA 02138 and assistant professor of political science (on leave), Southern Illinois University, Carbondale, IL 62901-4501 (jbarabas@rwi.harvard.edu). Toby Bolsen is a Ph.D. candidate of political science, Northwestern University, 601 University Place, Evanston, IL 60208 (t-bolsen@northwestern.edu).

We thank the following people for helpful comments and assistance: Scott Althaus, John Benson, Bob Blendon, Jake Bowers, Jamie Druckman, Tobin Grant, Bill Jacoby, Jim Kuklinski, Scott McClurg, Bob Luskin, Steve Nicholson, Skip Lupia, Jeff Mondak, Markus Prior, Paul Quirk, Jas Sekhon, and participants in workshops at the University of Connecticut, Harvard University, and Northwestern University. The Roper Center for Public Opinion Research provided the survey data used in these analyses.

American Journal of Political Science, Vol. 50, No. 2, April 2006, Pp. 266-282 
education and political knowledge. We find that higher levels of information in the environment elevate knowledge for everyone, but the educated learn disproportionately more from newspaper coverage. Increases in television coverage, by contrast, benefit the least educated almost as much as the most educated. Thus, the environment has a nuanced effect: certain news formats reinforce existing differences in political knowledge; others diminish those differences.

\section{The Study of Political Knowledge and Knowledge Gaps}

Scholars have long recognized the role that opportunity, or the availability of information, plays in the acquisition of political knowledge (e.g., Delli Carpini and Keeter 1996; Luskin 1990). And yet, with the exception of a handful of studies (e.g., Althaus 2003; Delli Carpini, Keeter, and Kennamer 1994; Hutchings 2001; Nicholson 2003), the overwhelming tendency has been to focus on the individual-level correlates of knowledge. ${ }^{1}$ Though this literature has generated important insights, the characteristics which tend to be associated with high levels of knowledge are either fixed (e.g., race, gender) or they change slowly (e.g., education, income). As a result, the conclusions generated by this body of work are rather pessimistic. Those who are the most likely to possess knowledge to begin with (i.e., individuals with high socioeconomic status) are the best equipped to add to their store of political knowledge. The "informationally rich get richer," to use Price and Zaller's $(1993,138)$ words, while the bottom dwellers of the knowledge distribution remain information poor (Converse 1990).

Moreover, the few studies examining environmentallevel correlates of knowledge paint an incomplete picture. There is evidence that increasing the opportunity to learn about politics - through front-page coverage in the media (Nicholson 2003) or geographical proximity to a news source (Delli Carpini, Keeter, and Kennamer 1994) — raises aggregate levels of political awareness (also see Delli Carpini and Keeter 1996, 121). At the same time, work by Hutchings $(2001,2003)$ indicates that the environment might work more selectively. He finds that cues in the political environment motivate greater levels of

\footnotetext{
${ }^{1}$ For example, Delli Carpini and Keeter state: "the information environment ... varies with great consequence for how well the public is able to comprehend the political world." They also acknowledge that their model "is a closed system based entirely on factors specific to the individual and does not take account of external factors critical to political learning" $(1996,209)$.
}

attentiveness for the particular subgroups (e.g., women, African Americans) most affected by an issue. On the whole, then, political scientists are just beginning to understand how variations in media coverage affect citizen knowledge (Hutchings 2001, 847). The extent to which the information environment reinforces the relationship between socioeconomic status and political knowledge remains largely unsettled.

Some important insights have come from other disciplines, however. In a now classic study in the field of speech communications, Tichenor, Donohue, and Olien (1970) observed that infusions of information into society have an uneven effect on citizen knowledge. Those who have attained a higher level of formal education show greater gains than those with fewer years of formal schooling, leading to "knowledge gaps." According to this body of work, the information environment has a powerful indirect influence, with increases in media publicity strengthening the association between education and knowledge.

Although dozens of studies have investigated and found support for the knowledge gap hypothesis, this literature suffers from an important limitation. Few studies include actual measures of media content, relying instead on self-reported measures of media exposure to estimate the effect of the information environment (see Gaziano 1997 for a review). One common approach is to examine the correlation between education and knowledge for individuals high in media use versus those low in media use-with the expectation that the correlation will be strongest for the former (e.g., Eveland and Scheufele 2000; Kwak 1999; McLeod, Bybee, and Durall 1979). As others have noted, this approach does not demonstrate that the knowledge gap between the least and the most educated is actually caused by media coverage (Gaziano 1983; Kleinnijenhuis 1991). Nor does it shed light on which features of the news lead to the formation of gaps in the first place. ${ }^{2}$

We address this void in the literature by content analyzing news coverage across a wide array of domestic and foreign policy issues and then directly linking variations in media content to political knowledge on these same

\footnotetext{
${ }^{2}$ Tichenor, Donohue, and Olien (1970) describe other ways of testing the knowledge gap hypothesis-for example, examining the correlation between education and knowledge for issues that receive varying amounts of media coverage or for a single issue over time (on the assumption that time is a proxy for changing levels of media coverage). Another approach is to interact respondent education with some measure of time and then examine the relationship between this interaction and knowledge (Holbrook 2002; Rhine, Bennett, and Flickinger 2001). Despite the variety of ways the knowledge gap hypothesis has been tested, Gaziano's characterization remains valid: "Very little research with data on associations between knowledge and education has involved mass media coverage of issues and news topics as a variable" $(1983,474$, emphasis in original).
} 
topics (also see Price and Czilli 1996). In particular, we are interested in whether the relationship between socioeconomic status and political knowledge varies (strengthening, weakening, or disappearing altogether) across issues receiving different amounts of media coverage. In the end, we provide one of the most rigorous tests of the knowledge gap thesis to date. We also extend the work of others who have simulated the effect of the environment by providing information to respondents in survey-based experiments (e.g., Gilens 2001; Kuklinski et al. 2000; Kuklinski et al. 2001).

\section{Hypotheses}

There are several reasons, mainly cognitive in nature, why the relationship between education and knowledge should become stronger in an informationally rich environment. Simply consider Graber's depiction of contemporary media coverage:

News stories often overwhelm people with more facts and figures and even pictures than they can readily absorb ... Stories are routinely written or narrated at an eighth-grade, or even twelfthgrade, comprehension level that ignores the fact that most American adults do not function comfortably above a sixth-grade level. $(2004,558)$

Compared to the less educated, individuals with more years of formal schooling are better able to digest the information in news stories. Not only is their reading ability likely to be greater, but they also are better at sorting and storing key points of information (Robinson and Levy 1986; also see Price and Zaller 1993, 138). ${ }^{3}$

Following Tichenor, Donohue, and Olien (1970), we expect that as the volume of information about a topic increases, every one will gain knowledge but at different rates. More formally, we hypothesize that increases in the overall amount of media attention to an issue will increase the average amount of knowledge in the population (Hypothesis 1a), but that the gap in knowledge between individuals with low and high levels of education also will increase (Hypothesis 1b). Rather than allowing

${ }^{3} \mathrm{~A}$ similar dynamic has been observed in studies of priming, in which well-informed individuals are more likely to manifest priming effects than their least-informed counterparts (Krosnick and Brannon 1993). The difference arises from the ability of the wellinformed to understand news content, store the information or its implications in memory, and retrieve it at a later date. the less educated to "catch up," increasing the amount of media coverage reinforces the positive relationship between education and political knowledge. ${ }^{4}$

If knowledge gaps appear because of cognitive differences across individuals with low and high levels of education, more cognitively taxing news formats should reinforce those gaps, while less cognitively taxing formats ought to diminish them. Indeed, Neuman, Just, and Crigler (1992) show that differences in the format of print and broadcast coverage influence the extent to which people learn from the news. They find that the first few paragraphs of newspaper stories are dominated by facts as opposed to explanatory devices such as framing or analysis. Other scholars have noted that the complex and compactly written stories of print news outlets require a certain level of literacy (Graber 1994; also see Kleinnijenhuis 1991). Television, by contrast, is better able to exploit the dramatic and emotional components of a news story through visuals (Graber 2004). Often, the visual component of a news story is consistent with or complementary to the verbal content (Neuman, Just, and Crigler 1992), making information more accessible to those with weaker cognitive skills.

Based upon these studies, we can refine our expectations regarding the influence of the information environment to include the following hypotheses. All else held constant, increasing the amount of newspaper coverage will raise the average level of knowledge in the population, but it should primarily benefit those with high levels of education (Hypothesis 2a). Restated, we expect increases in print coverage to boost the intercept (i.e., the average level of knowledge in a given survey) and to strengthen the relationship between education and knowledge. The effect of television is more subtle. Those with low levels of education likely learn more, in relative terms, than their more educated peers, but it is doubtful that they learn enough to completely eliminate the information advantage of the most educated (e.g., Freedman, Franz, and Goldstein 2004, 733-34). Therefore, Hypothesis $2 \mathrm{~b}$ states that an increase in television coverage will raise the average level of knowledge in the population, but it will not alter the relationship between education and knowledge (i.e., no statistically meaningful effect in either direction).

\footnotetext{
${ }^{4}$ Hypothesis 1a implies a positive intercept shift in environments with abundant political information. Hypothesis $1 \mathrm{~b}$ entails a strengthening of the relationship between education and knowledge (represented by an increase in the size of the coefficient on education). We follow in the tradition of the knowledge gap literature and focus on education, the most important predictor of political knowledge (Delli Carpini and Keeter 1996) and one of the most commonly used measures of socioeconomic status.
} 
We test both of these hypotheses in the second part of our study. ${ }^{5}$

\section{Data and Methods}

Our use of the term "environment" is distinct from scholars who study the influence of contextual factors, such as neighborhoods or workplaces (e.g., Huckfeldt 2001; Krassa 1990; Mutz and Mondak 2006). We also distinguish ourselves from those who study the broader political environment, such as district competitiveness or institutional arrangements (e.g., Gordon and Segura 1997; Hutchings 2001, 2003; Smith 2002). Instead, we focus on the information people are exposed to in the media. This includes statements made by public officials, interest groups, journalists, and other actors regarding political developments and policy issues (Kuklinski et al. 2001). In making this distinction we do not deny the role that neighborhoods, workplaces, and other contexts play in filtering information citizens receive from the mass media. ${ }^{6}$

To test our hypotheses regarding the information environment, we combined more than three dozen public opinion surveys and collected data on the availability of information prior to each one of these surveys. Our first study examines a series of knowledge questions on two issues that gained prominence in the late 1990s (the tobacco settlement with the states and congressional proposals on Medicare). Our second study examines 41 issues over a period of 10 years. The magnitude of this data collection effort required that a number of decisions be made regarding the measurement of knowledge and the information environment. We summarize the most important of these decisions here and provide additional details in the appendix.

\section{Measuring Knowledge}

Traditionally, political knowledge has been categorized as either general or domain specific (Delli Carpini and Keeter 1996; Gilens 2001; Zaller 1992). General, or chronic,

\footnotetext{
${ }^{5}$ These ideas also have their roots in the knowledge gap literature (e.g., Eveland and Scheufele 2000; Kwak 1999). As discussed earlier, however, these studies do not incorporate measures of media content, making it difficult to explore the mechanism behind the differential effects of print and television news (e.g., Miyo 1983).

${ }^{6} \mathrm{We}$ also distinguish ourselves from the literature on campaign effects. While there is evidence that learning takes place in election campaigns (e.g., Alvarez 1997; Brians and Wattenberg 1996; Freedman, Franz, and Goldstein 2004), few studies directly examine the information environment as we do below (but see Druckman 2005; Just et al. 1996).
}

knowledge consists of civics-style facts one might learn from a textbook, such as the branch of the federal government which can declare laws unconstitutional or the vote margin needed in Congress to overturn a presidential veto. By contrast, policy- or domain-specific knowledge represents facts about particular programs, policies, or problems, such as the percent of the budget devoted to foreign aid or recent trends in the crime rate (e.g., Gilens 2001; Iyengar 1990).

General measures are widely available and therefore tend to be used more frequently (Gilens 2001, 380), but they suffer from an important limitation. Once general knowledge is obtained, the typical citizen might go years, decades, or even a lifetime without the need to update their knowledge of who occupies the vice presidency, which party controls the House of Representatives, or the protections guaranteed by the First Amendment (Graber 2004, 561). For this reason, domain-specific measures are preferable for examining the impact of the information environment. In this study, we focus on a particular kind of domain-specific knowledge-news events (Price and Zaller 1993) or what Delli Carpini and Keeter call "surveillance facts" $(1991,598)$. Survey questions about these topics have one essential quality: knowing the correct answer depends upon recent exposure to information in the media rather than learning that occurred years ago.

Focusing on surveillance knowledge is appropriate for another reason. In recent years, scholars have questioned the notion that citizens need a large store of general knowledge in order to function in a democratic society (Lupia and McCubbins 1998; see Leighley 2004, 151-61, for a discussion). The outlines of a new standard can be seen in the work of Schudson (1998), who frames citizenship in terms of a monitorial obligation. According to this view, citizens should be knowledgeable about acute problems and pressing issues that appear in the headlines, but little else. In contrast to the person who follows public affairs in all their details, the monitorial citizen intermittently surveys political news. With more scholars embracing this view of citizenship (e.g., Graber 2004; Zaller 2003), understanding how people acquire surveillance knowledge is of great normative interest. ${ }^{7}$

Our study employs 41 cross-sectional public opinion surveys administered by Princeton Survey Research Associates (PSRA) from 1992 to 2003. These surveys asked respondents about recent political developments (e.g., "Does the Clinton health care reform plan guarantee that workers do not lose their health insurance coverage, if they

\footnotetext{
${ }^{7}$ To the extent that people make "online" judgments (e.g., Lodge, Steenbergen, and Brau 1995), their ability to recall surveillance facts may not indicate how responsive they are to the information environment.
} 
lose or quit their jobs, or doesn't the plan go that far?"), and hence they are more topical than general knowledge questions. However, it was precisely because the questions asked respondents about specific, recent political developments that we expected to observe a relationship between features of the information environment and performance on the knowledge questions. The dependent variable in our analysis is a dichotomous measure coded " 1 " if the respondent answered the knowledge question correctly and "0" otherwise. ${ }^{8}$

\section{Individual-Level Predictors}

Following in the tradition of researchers who have examined the individual-level predictors of political knowledge (e.g., Bennett 1988; Delli Carpini and Keeter 1996; Neuman 1986), we included measures of education, income, age, race, and gender in our models. ${ }^{9}$ In addition, several studies have documented that following politics in the news is associated with higher levels of political knowledge (Delli Carpini and Keeter 1996; Luskin 1990). Like previous scholars, we view the "follows" measure as conveying important information about exposure to the information environment (Dalton, Beck, and Huckfeldt 1998; Hetherington 1996). The follows measure used below improves upon past research because it is specific to the particular surveillance issue mentioned in the knowledge question (e.g., "How closely have you been following the debate over health care reform?"). ${ }^{10}$

\section{The Information Environment}

We conducted a content analysis of the full text transcripts of three national media outlets during the six weeks prior

${ }^{8}$ We combine incorrect and "don't know" responses (Luskin and Bullock 2005). Randomly reassigning "don't know" responses (Mondak 2001) or including a dummy variable when respondents were reminded of the option to say "don't know" did not alter our conclusions.

${ }^{9}$ The range and coding for the variables are as follows: education $(1-7 ; 7=$ post-graduate $)$, income $(1-6 ; 6=\$ 100,000+)$, age $(18-$ $97 ; 97=97$ years old $)$, black $(0-1 ; 1=$ African American), female $(0-1 ; 1=$ female). Missing demographic responses were imputed to avoid listwise deletion of approximately $20 \%$ of our cases. Using the Amelia computer software, we created ten data sets of imputed values, conducted our empirical analyses on each new dataset, averaged the coefficients, and adjusted the standard errors for estimation uncertainty (King et al. 2001, 53).

${ }^{10}$ Coding categories are: $1=$ not at all closely; $2=$ not too closely; 3 = fairly closely; $4=$ very closely. The causal relationship may run in the opposite direction-i.e., knowledge about a particular issue may stimulate one to follow that topic in the news. In separate analyses we explored the possibility of endogeneity. Our key substantive findings hold whether we employ alternate specifications that account for endogeneity or exclude follows from the analysis altogether. to the first day of each PSRA survey. The choice of a sixweek coding period was deliberate. The sponsors of the PSRA surveys designed knowledge questions in response to political developments occurring during this period of time (Brodie et al. 2003).

We use the Associated Press (AP) to represent the total amount of media attention devoted to an issue. This decision can be justified on a number of grounds. As the major newswire service in the United States, the AP serves 5,000 radio and television stations (http://www.ap.org) and nearly all of the nation's daily newspapers (Graber 2002, 44). While few people actually read the $A P$ newswire, it influences news coverage widely and serves as a good proxy for the amount of information in the environment at any given time.

In Study 2, we concentrate on differences between print and television coverage. For our broadcast source, we randomly selected one television station from the three major networks and content analyzed its evening news program (CBS Evening News). We selected USA Today as our print source because of its wide distribution. The daily audience for this paper is 5.2 million people (http://www.usatoday.com), earning it the nickname "the nation's most read daily newspaper."11 Like our use of the AP, we view CBS and USA Today as providing a representative picture of the information that was appearing on television and in newspapers around the county.

Once we identified the relevant sample of news stories in each media outlet, we tallied the total number of stories mentioning the correct answer during the content analysis period. ${ }^{12}$ A simple story count captured the essence of what we sought to measure-namely, the degree to which information about a particular issue was plentiful. We coded stories for other characteristics, such as expert commentary and backgroundoriented contextual coverage, which we return to in our discussion of the empirical findings at the conclusion of Study $2 .^{13}$

\footnotetext{
${ }^{11}$ Among major national newspapers (USA Today, Wall Street Journal, and the New York Times) the market share of USA Today is $44 \%$ (http://www.usatoday.com).

${ }^{12} \mathrm{~A}$ story was considered relevant if it discussed the issue underlying the knowledge question. Intercoder reliability analyses indicate high levels of agreement for identifying relevant articles (kappa $=.71)$ and identifying articles containing the correct answer (kappa $=$ .84). According to Cicchetti and Sparrow (1981), a value of kappa above .60 is good; .75 or higher is excellent. Media reports for all three sources were obtained from Lexis-Nexis and evaluated by multiple coders. Coding and intercoder reliability were conducted at the article level.

${ }^{13}$ The kappa scores for our context and source codes were .67 and .58 , respectively.
} 


\section{Study 1: Variation in Media Coverage within an Issue}

Two of the 41 surveys in our sample asked respondents multiple questions about the same surveillance issue. Importantly, media coverage of the issue varied in a way that allows us to test Hypotheses 1a and 1b. The first surveillance issue we examine is the 1998 tobacco settlement with the states. There were multiple components of the deal (e.g., payments to the states, a ban on tobacco advertisements such as Joe Camel) each of which received different amounts of coverage in the media. Our second surveillance issue, congressional proposals on Medicare during 1997, is similar in the sense that Congress was considering several ideas (e.g., making the wealthy pay higher premiums, increasing patient choice), each of which received more or less coverage in the news. Thus, in both surveys, the same individual is asked multiple questions about the same issue. For any given respondent, variation in knowledge across the questions can be attributed to differences in the amount of media coverage devoted to particular aspects of the tobacco settlement or Medicare.

And differences in media coverage there were. When it came to the tobacco settlement, the media focused almost exclusively on one feature of the deal: the billions of dollars that the tobacco industry was to pay to the states. In the six weeks leading up to the PSRA survey, this aspect of the deal was covered in 28 Associated Press stories (approximately one story every other day). Other parts of the settlement, such as the ban on advertisements, received a moderate amount of attention (11 stories), while still others, such as the right of individuals to sue the tobacco industry, received little media attention (4 stories). Coverage of Medicare was similarly uneven. The media paid the most attention to proposals that made the wealthy pay higher premiums (25 stories). Giving seniors more choice under Medicare received some coverage (11 stories), while means testing for benefits received no attention ( 0 stories). We expect these differences in media coverage to be related to variations in political knowledge within each survey. ${ }^{14}$

Hypothesis 1a leads us to expect that the average level of knowledge among survey respondents will be highest for those topics receiving the most media attention. Aggregate patterns of political knowledge follow precisely this pattern. Over $70 \%$ of respondents correctly answered questions regarding the billion dollar payment to the states and the ban on advertisements.

\footnotetext{
${ }^{14}$ The other factor that is varying is how the individual questions regarding tobacco and Medicare were worded. We deal more systematically with question difficulty in Study 2.
}

\section{FIGURE 1 The Varying Relationship Between Education and Knowledge}

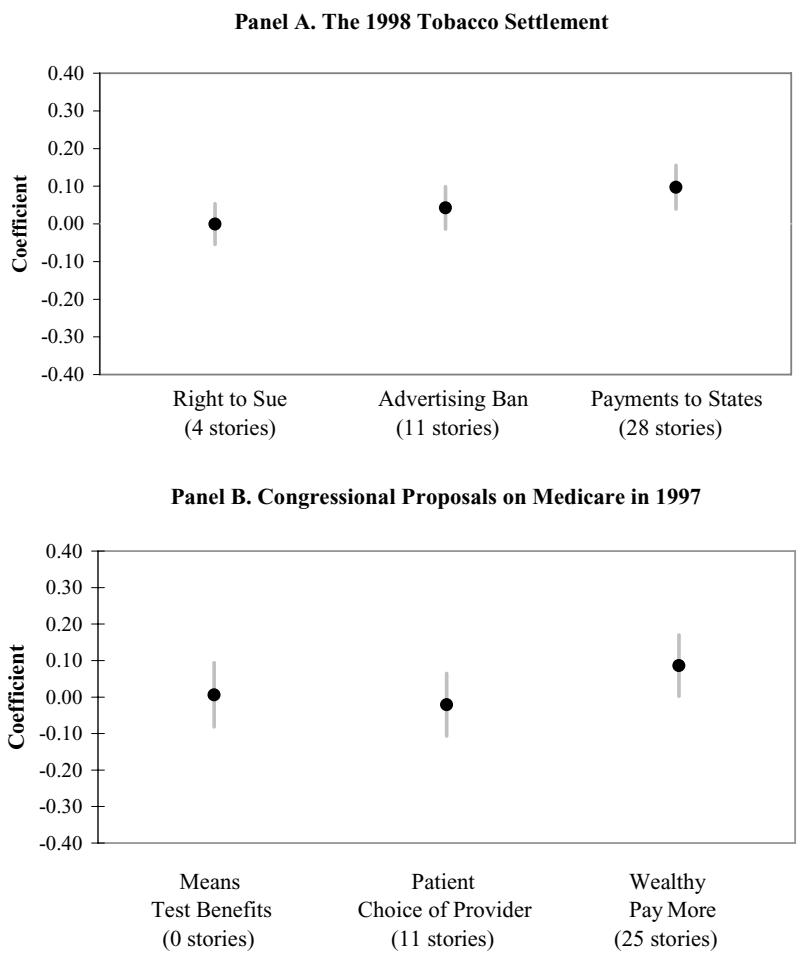

Note: Solid black dots denote the education coefficient values. Gray lines represent 95\% confidence intervals.

Only $25 \%$ of respondents correctly answered the question regarding the right to sue, the topic that received the least attention in the news ( $t$-tests for differences in knowledge significant at $\mathrm{p}<.01$ ). On Medicare, $62 \%$ of the sample correctly answered questions about the most heavily covered topic (wealthy pay more); $47 \%$ correctly answered the question about patient choice, and only $37 \%$ provided the right answer to the question about means testing for benefits ( $t$-tests significant at $\mathrm{p}<.01)$. Again, these patterns follow the level of coverage devoted to each issue.

Due to the cognitive differences between individuals with low and high levels of education, the least educated are the least equipped to process increases in the amount of political information. Accordingly, Hypothesis $1 \mathrm{~b}$ predicts that the relationship between education and knowledge will become stronger as media coverage increases. This pattern is shown in Panel A of Figure 1, which displays the coefficient on education from a probit model predicting knowledge. ${ }^{15}$

\footnotetext{
${ }^{15}$ We ran a multivariate probit (Greene $2003,714-19$ ) that included the usual array of individual-level predictors: education, income, age, gender, race, and whether the respondent was following news
} 
The coefficients are arranged in order of increasing media coverage. For example, the left-most coefficient $(\hat{\beta}=-.001$; standard error $=.027)$ represents the relationship between education and knowledge on the part of the settlement that received the least coverage (the right to sue). This relationship is statistically insignificant, as indicated by the $95 \%$ confidence interval that overlaps zero. Consistent with our expectations, this relationship is weaker than the relationship between education and knowledge on the two tobacco topics that received more coverage (ad ban, payments to the states). ${ }^{16}$

To put the coefficients in perspective, consider the gap in knowledge between two typical respondents, one with a high school degree and the other with schooling after college. ${ }^{17}$ When it comes to the right to sue, a highly educated respondent is no more likely to provide the correct answer to the question than a poorly educated respondent $(23 \%$ for both). The confidence intervals around these predictions are large and overlap considerably. As media coverage increases, both individuals are more likely to correctly answer questions about the settlement, but it is the highly educated person who benefits the most from an increase in media coverage. For the most heavily covered topic (payments to the states), a person with low education has a $65 \%$ chance of correctly answering the question (95\% C.I. from 61 to $69 \%$ ). A respondent with high education has a $77 \%$ chance of getting the question correct ( $95 \%$ C.I. from 72 to $82 \%$ ), translating into a 12-percentage-point knowledge gap.

Figure $1 \mathrm{~b}$ presents education coefficients for questions about congressional proposals on Medicare. The coefficients are arrayed in terms of the level of media coverage for each proposal (low, medium, or high). For the most part, Figure $1 \mathrm{~b}$ reproduces the pattern seen in Figure 1a: an insignificant relationship between education and knowledge when the amount of media coverage is low (or moderate) and a positive and significant relationship when media coverage is high. ${ }^{18}$ Like the previous models, the gap between the least and most educated is

about the tobacco settlement (or Medicare). See the appendix for the table of coefficients.

${ }^{16}$ Using a nonlinear Wald test, the difference between the coefficient in the right to sue model is significantly different than the coefficient in the payment to states model $(\mathrm{p}<.01)$. The ad ban vs. payment to the states comparison also is significant $(\mathrm{p}<.10)$.

${ }^{17}$ The typical respondent is a white female who takes on the average value of all other variables.

${ }^{18}$ The coefficient in the patient choice model is significantly different from the coefficient in the wealthy pay more model ( $\mathrm{p} \leq$ $.05)$. largest for the aspect of the issue receiving the most news coverage. ${ }^{19}$

Looking at the same respondents across the same issue (either tobacco or Medicare), we have shown that variations in the level of knowledge correspond to differences in the amount of news coverage. We also have shown that the well-known relationship between education and knowledge is not fixed-not even within the same issue. How generalizable are these findings? We turn to that question next.

\section{Study 2: Variation in Media Coverage across Issues}

In this study, we pooled 41 public opinion surveys and collected data on the availability of information prior to each one of the surveys. Although the subject of these questions varies over time, they are equivalent measures of knowledge in at least one respect: they have passed Zaller's (2003) "burglar alarm" news standard, which is to say that they represent important issues journalists were covering in the weeks leading up to the survey (also see Schudson 1998). ${ }^{20}$ Put somewhat differently, whereas Study 1 had a high degree of internal validity, Study 2 has a high degree of external validity.

To return to our central claim, we argue that in addition to the individual-level predictors of knowledge, variation in the information environment affects what citizens know about politics. Thus, the first step was to document that knowledge of recent political developments changes across the 41 surveys in our study. If it did not, there would be little reason to look beyond the stable individual-level factors that are associated with knowledge.

Figure 2 presents the percentage of respondents giving the correct response to a question tapping their

\footnotetext{
${ }^{19}$ There were two other Medicare questions in the survey. The first asked about a proposal to cut provider payments. This topic received about the same amount of coverage as the proposal to increase patient choice (12 stories), and roughly the same percentage of respondents ( 45 and $47 \%$, respectively) could answer these items correctly. The other question asked about proposals to increase the eligibility age. This topic received about the same amount of coverage as making the wealthy pay more (22 stories), and, once again, roughly the same number of people (56 and $62 \%$, respectively) provided the correct answer to these questions. We report the education coefficients for these models in Table A2. The pattern in this table suggests the possibility of nonlinear effects; we address this more systematically in Study 2.

${ }^{20}$ Because all of these issues represent important, not just recent, political developments, every one of the issues we examine in Study 2 was covered by at least one of our three media sources.
} 


\section{FIGURE 2 The Distribution of Knowledge: Surveillance Issues}

1992-2003

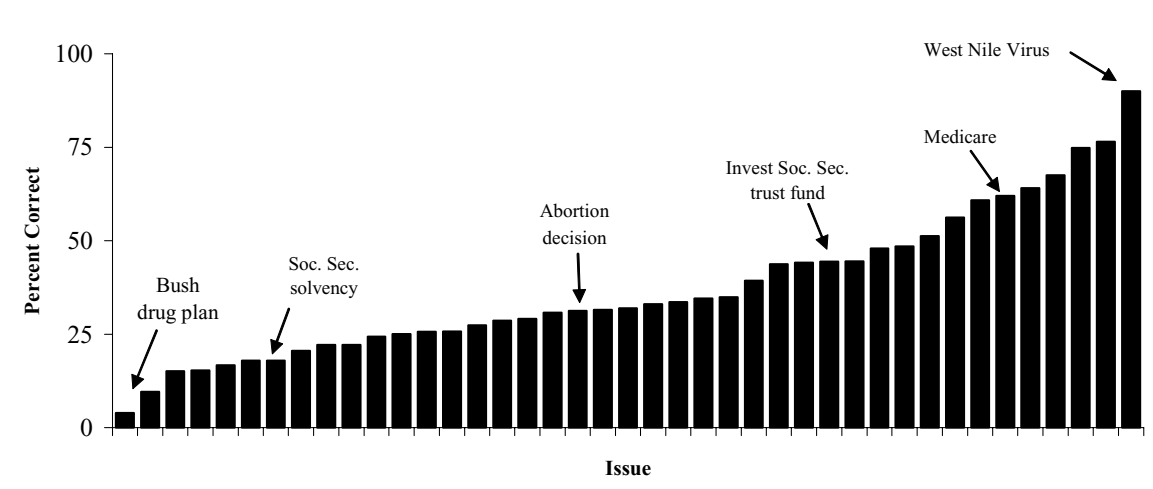

knowledge of surveillance issues from 1992 to 2003. As Figure 2 demonstrates, levels of political knowledge were anything but constant across the topics queried in the PSRA surveys, ranging from a low of $4 \%$ (President Bush's drug plan) to a high of $90 \%$ (West Nile Virus). There also is no obvious pattern to citizen knowledge on this sample of issues. Citizens are no more-or less-knowledgeable about partisan issues (compare, for example, the varying levels of knowledge about Social Security, Medicare, and abortion). We remain hopeful, then, that at least some portion of political knowledge can be linked to changing levels of media coverage across these subjects.

Like the two issues we examined in Study 1, there was a great deal of variation in media attention to the 41 issues. The mean level of coverage in the $A P$ was ten news stories. The variation around that mean was substantial, however, with some issues receiving no coverage and others as many as 39 stories. As for the volume of print coverage, the mean number of stories in USA Today was five $(\min =0$; $\max =$ 17). The average number of stories on CBS Evening News was two $(\min =0 ; \max =7)$.

Hypothesis la predicts that the average level of knowledge among survey respondents will be positively related to the volume of information in the media. An explicit test of this proposition will come later, when we combine our surveys and examine whether the variation in the intercept is significantly greater than zero. In the meantime, we see support for Hypothesis 1a in the aggregate-level relationships. The bivariate correlation between our media measures and the knowledge series ranges from .50 to $.63(\mathrm{p}<.01)$. The outline of this relationship can be seen in Figure 2. There were three stories in the AP about the Bush drug plan and Social Security solvency, 12 on the Supreme Court's abortion decision, 16 about investing the Social Security trust fund, 24 on the subject of Medicare premiums, and 33 about West Nile Virus.

\section{FIGURE 3 Knowledge across Education Groups on Issues with Low and High Media Coverage}
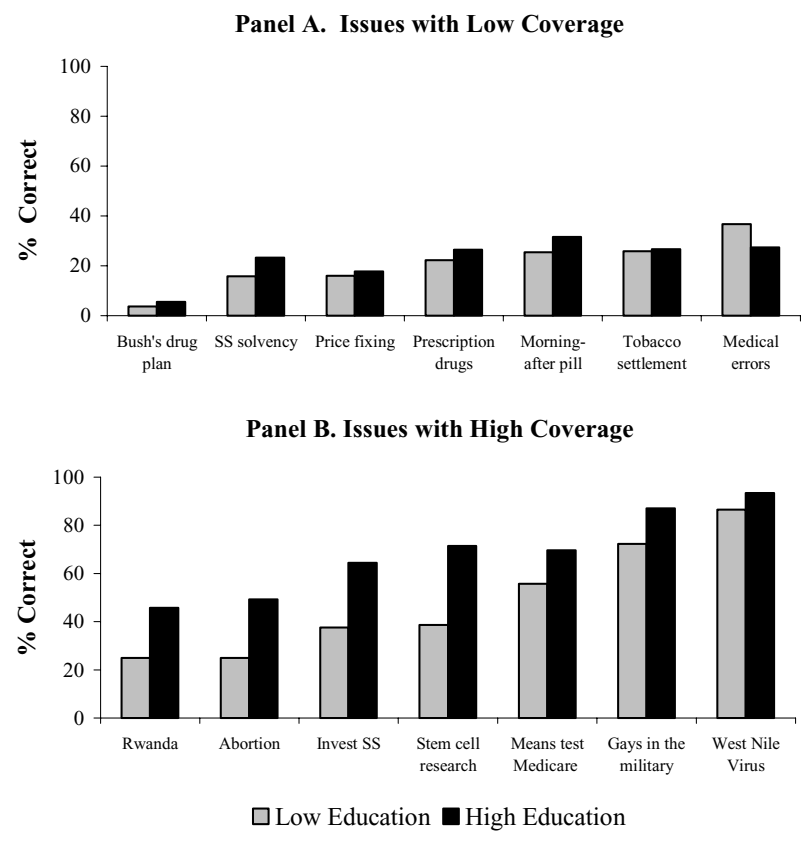

We also see some initial support for Hypothesis $1 \mathrm{~b}$ which states that the knowledge gap between the least and the most educated will be largest on issues with the most media coverage. Figure 3 shows the percent correct across education groups for the seven least and most covered issues (which corresponds roughly to the lower and upper quintiles of our sample). For issues that receive relatively little coverage, there is no consistent pattern between a person's level of education and what they know about recent political developments. On some issues the highly educated know more (e.g., Social Security 
solvency), while on others the least educated appear to know more (medical errors) or there is no difference between the two groups (the tobacco settlement). The average knowledge gap across these seven issues is 2 percentage points. Panel B, by contrast, shows that on issues with high levels of media coverage, there is a consistent gap between education groups. The average size of this gap is 20 percentage points, and it ranges from 7 percentage points (West Nile Virus) to 33 percentage points (stem cell research).

Having shown that the relationship between education and knowledge varies (also see Figure 1, Study 1), we turn next to the role that media coverage plays in accounting for the variance in this relationship. Because we are combining 41 cross-sectional surveys, subtle differences in survey topics or questions might affect patterns of political knowledge. One obvious factor is the inherent difficulty of the question. When respondents are confronted with a question that is worded in a confusing manner or when they are queried about a complex subject, the mean of all respondents answering this item will be lower than we would otherwise expect. In our next and final set of analyses, we employ an item-response model (Hambleton and Swaminathan 1985; Lord and Novick 1968) to create a measure of question difficulty. We use this variable to control for differences across surveys. In its original form, Item Difficulty represents the objective probability of correctly answering a knowledge question. We subtracted the variable from 1 so that higher values indicate a more difficult question. ${ }^{21}$

\section{A Multilevel Model}

Our data combine survey respondents who are nested in different information environments, which is to say that we have data at two levels. The first is the level of the individual survey respondent; the second corresponds to the information environment preceding each survey. Because individuals in any given survey confront similar information environments, there is a significant amount of clustering in our data. In this situation, multilevel models are an appropriate solution (Raudenbush and Bryk 2002; Goldstein 2003).

Given our argument, a multilevel model entails the specification of three equations:

$$
\begin{aligned}
\text { Knowledge }_{i j}= & \beta_{0 j}+\beta_{1 j} \text { Education }_{i j}+\cdots \\
& +\beta_{k} x_{k i j}+\varepsilon_{i j}
\end{aligned}
$$

\footnotetext{
${ }^{21}$ We also operationalized question difficulty in terms of the number of response options and the number of words in the question. Neither variable was statistically significant in our models.
}

$$
\begin{aligned}
& \beta_{0 j}=\gamma_{00}+\gamma_{01} \text { Volume }_{j}+\gamma_{02} \text { Difficulty }_{j}+\delta_{0 j} \\
& \beta_{1 j}=\gamma_{10}+\gamma_{11} \text { Volume }_{j}+\gamma_{12} \text { Difficulty }_{j}+\delta_{1 j}
\end{aligned}
$$

Equation (1) models the relationship between the usual suspects (education, age, income, etc.) and political knowledge. The multilevel model departs from the typical regression in that the parameters in the first equation are allowed to vary across the $j$ level-two units. Thus, equation (2) models the intercept $\left(\beta_{0 j}\right)$, the variation in the average level of knowledge among a group of survey respondents, as a function of the volume of information in the environment (measured in terms of the $A P, C B S$, or USA Today) and the inherent difficulty of the question. The third equation models the variation in the education parameter $\left(\beta_{1 j}\right)$ as a function of these same factors. The relationship posited by equation (3) commonly is referred to as a "cross-level interaction" because it involves the relationship between a level-one and a level-two predictor. ${ }^{22}$

According to Hypothesis 1a, increases in the overall volume of the information environment will raise the average level of knowledge (i.e., $\gamma_{01}$ will be positive and significant). Hypothesis $1 \mathrm{~b}$ predicts that most of this increase will take place among the most educated, leading to a strengthening of the relationship between education and knowledge in high volume environments (i.e., $\gamma_{11}$ will be positive and significant). We expect that increases in the amount of newspaper coverage will strengthen the relationship between education and knowledge (Hypothesis 2a), which again implies a positive sign for the cross-level interaction between the volume of newspaper coverage and education. Increases in the amount of television coverage should have no effect on that relationship (Hypothesis $2 \mathrm{~b}$ ), leading to an insignificant cross-level interaction between the volume of television coverage and education.

A useful starting point in the analysis of multilevel data is the random effects ANOVA model (Raudenbush and Bryk 2002, 24). In this representation,

$$
Y_{i j}=\gamma_{00}+\delta_{0 j}+\varepsilon_{i j}
$$

the probability of correctly answering a question is modeled as a function of $\gamma_{00}$, the grand mean of $Y$. The model

\footnotetext{
${ }^{22}$ Equations (2) and (3) also include disturbance terms ( $\delta$ ). One of the virtues of multilevel models is that researchers do not assume the level-two variables account perfectly for the variation in the level-one parameters (Steenbergen and Jones 2002, 221). Most existing studies that examine the environmental-level influence on knowledge implicitly make such an assumption.
} 
also includes two random parameters. The first, $\delta_{0 j}$ represents a survey-level random effect while the second, $\varepsilon_{i j}$, represents an individual-level random effect. What makes this model particularly useful is the fact that it decomposes the variance in Knowledge across levels of analysis. Thus, we can determine how much between-survey variation $\left(\tau_{00}\right)$ there is relative to within-survey variation $\left(\sigma^{2}\right)$. For example, the ratio of $\tau_{00}$ to the total variance $\left(\tau_{00}+\sigma^{2}\right)$ indicates how much of the variance in knowledge can be attributed to environmental-level factors. Given the importance of individual-level factors in predicting knowledge, it should come as little surprise that approximately $75 \%$ of the variance in this variable can be attributed to the individual-level. Importantly, however, $25 \%$ of the variance is attributable to environmental-level factors. Scholars have long acknowledged that the information environment has an important influence on knowledge; this study is the first to estimate the relative magnitude of that influence. ${ }^{23}$

Table 1 reports the results of two multilevel models where the first corresponds to the overall information environment, using Associated Press coverage as a proxy, and the second compares the effect of newspaper (USA Today) and broadcast (CBS Evening News) coverage. ${ }^{24}$

We begin by presenting the coefficients for the levelone fixed effects. These terms represent the average effect of each level-one variable across our sample of issues. Focusing on the first column, the Education coefficient, $\hat{\beta}_{1}=.071$ (standard error $=.008$ ), represents the estimated average slope for education across the 41 surveys. The fact that the coefficient is positive and significant confirms decades of studies showing a relationship between education and political knowledge. Other level-one predictors perform exactly as one would expect given past research in this area. Higher levels of political knowledge are associated with having a high income, being older, male, white, and following a particular issue in the news.

\footnotetext{
${ }^{23}$ Another way of illustrating the importance of between-survey variation in our data is a Wald test, where the null hypothesis states that $\tau_{00}=0$ (Rasbash et al. 2000, 108). We reject the null $\left(\chi^{2}=\right.$ 20.235 ; 1df; $\mathrm{p}<.01)$ and conclude that the variation in $\tau_{00}$ is significantly greater than zero (i.e., the intercept should be specified as a random parameter). We also estimated a random coefficients model in which we treat the education parameter as a random variable (i.e., $\beta_{1 j}=\gamma_{10}+\delta_{1 j}$ ). We conducted a Wald test, where the null hypothesis states that the variance component for education is equal to zero. We reject the null $\left(\chi^{2}=6.183 ; 1 \mathrm{df} ; \mathrm{p}<.05\right)$ and conclude that the variation in the education coefficient is significantly greater than zero.

${ }^{24}$ Our dependent variable is dichotomous, so we use a probit link function. Statistical estimates were generated using MLwiN 2.0 (Rasbash et al. 2000) and R 1.9.1 (Pinheiro and Bates 2000). Continuous variables are grand mean centered (see Raudenbush and Bryk [2002] for a discussion).
}

TABLE 1 The Information Environment and Political Knowledge: Multilevel Statistical Estimates

\begin{tabular}{|c|c|c|}
\hline Parameter & $\begin{array}{c}\text { Overall } \\
\text { Information } \\
\text { Environment } \\
\text { Estimates } \\
\end{array}$ & $\begin{array}{c}\text { Newspaper vs. } \\
\text { Television } \\
\text { Estimates } \\
\end{array}$ \\
\hline \multicolumn{3}{|l|}{ Fixed Effects } \\
\hline Intercept & $\begin{array}{c}-0.281^{* *} \\
(0.065)\end{array}$ & $\begin{array}{c}-0.291^{* *} \\
(0.056)\end{array}$ \\
\hline Education & $\begin{array}{c}0.071^{* *} \\
(0.008)\end{array}$ & $\begin{array}{l}0.071^{* *} \\
(0.008)\end{array}$ \\
\hline Income & $\begin{array}{l}0.037^{* *} \\
(0.007)\end{array}$ & $\begin{array}{l}0.038^{* *} \\
(0.007)\end{array}$ \\
\hline Age & $\begin{array}{l}0.003^{* *} \\
(0.001)\end{array}$ & $\begin{array}{l}0.003^{* *} \\
(0.001)\end{array}$ \\
\hline Female & $\begin{array}{c}-0.091^{* *} \\
(0.032)\end{array}$ & $\begin{array}{c}-0.090^{* *} \\
(0.032)\end{array}$ \\
\hline Black & $\begin{array}{c}-0.073+ \\
(0.038)\end{array}$ & $\begin{array}{c}-0.073+ \\
(0.038)\end{array}$ \\
\hline Follows issue & $\begin{array}{l}0.270^{* *} \\
(0.016)\end{array}$ & $\begin{array}{l}0.270^{* *} \\
(0.016)\end{array}$ \\
\hline Item difficulty & $\begin{array}{c}-0.901^{* *} \\
(0.284)\end{array}$ & $\begin{array}{c}-0.833^{* *} \\
(0.228)\end{array}$ \\
\hline Newswire coverage & $\begin{array}{c}0.028^{* *} \\
(0.009)\end{array}$ & $\begin{array}{l}- \\
-\end{array}$ \\
\hline Newspaper coverage & $\begin{array}{l}- \\
-\end{array}$ & $\begin{array}{l}0.047^{* *} \\
(0.015)\end{array}$ \\
\hline Television coverage & $\begin{array}{l}- \\
-\end{array}$ & $\begin{array}{r}0.085^{*} \\
(0.043)\end{array}$ \\
\hline Education $X$ newswire & $\begin{array}{c}0.002^{*} \\
(0.001)\end{array}$ & $\begin{array}{l}- \\
-\end{array}$ \\
\hline Education $X$ newspaper & $\begin{array}{l}- \\
-\end{array}$ & $\begin{array}{l}0.004^{* *} \\
(0.002)\end{array}$ \\
\hline Education $X$ television & $\begin{array}{l}- \\
-\end{array}$ & $\begin{array}{c}0.002 \\
(0.003)\end{array}$ \\
\hline $\begin{array}{l}\text { Education } X \text { item } \\
\text { difficulty }\end{array}$ & $\begin{array}{c}-0.075^{* *} \\
(0.025)\end{array}$ & $\begin{array}{c}-0.072^{* *} \\
(0.024)\end{array}$ \\
\hline \multicolumn{3}{|l|}{ Variance Components } \\
\hline Intercept & $\begin{array}{l}0.186^{* *} \\
(0.034)\end{array}$ & $\begin{array}{l}0.132^{* *} \\
(0.021)\end{array}$ \\
\hline Education & $\begin{array}{l}0.003^{* *} \\
(0.001)\end{array}$ & $\begin{array}{l}0.002^{* *} \\
(0.001)\end{array}$ \\
\hline$N_{i} / N_{j}$ & $45365 / 41$ & $45365 / 41$ \\
\hline
\end{tabular}

Note : Table entries are maximum likelihood (IGLS/PQL) estimates with estimated standard errors in parentheses. The data have been weighted to reflect the U.S. population.

$+=p \leq .10,{ }^{*}=p \leq .05,{ }^{* *} p \leq .01$

The results for the individual-level predictors are similar across both models, so we instead concentrate on variables that have the most relevance for our theoretical argument.

Turning to the coefficients for the level-two fixed effects, we see support for Hypothesis 1a. The positive and 
significant coefficient on Newswire coverage indicates that even when we control for the difficulty of the question, an increase in the overall amount of media attention to an issue raises the average level of knowledge. Consistent with Hypothesis $1 \mathrm{~b}$, the coefficient on the cross-level interaction between Education and Newswire coverage is positive and significant. This implies that as the volume of information increases, the relationship between education and knowledge becomes stronger. ${ }^{25}$ Predicted probabilities put this last finding in perspective. ${ }^{26}$ In an environment devoid of information, the typical citizen with low education has a $22 \%$ chance of getting the correct answer on a knowledge question (95\% C.I. from 19 to 25\%). A more educated respondent has a $29 \%$ chance of providing the correct answer (95\% C.I. from 26 to 33\%), for an estimated knowledge gap of approximately 7 percentage points. The knowledge gap between these hypothetical citizens triples in an environment that is rich with information (the difference between 57 and 78\%).

The second column of results compares the conditioning role of newspaper and television news coverage. Focusing first on the level-two fixed effects, an increase in either news source is positively associated with knowledge. In other words, variation in aggregate political knowledge across surveys can be attributed to differences in the amount of newspaper and television coverage. Going from the minimum to the maximum on print and broadcast coverage results in 30 and 23 percentage point increases in aggregate political knowledge, respectively.

The coefficients on the cross-level interactions ( $E d u$ cation $X$ newspaper and Education $X$ television) also show support for our hypotheses. Higher amounts of print coverage strengthen the relationship between education and knowledge, while television has no effect on that relationship. The substantive effect of both terms is best displayed graphically.

Consistent with Hypothesis $2 \mathrm{a}$, the first panel of Figure 4 shows that the highly educated benefit the most from an increase in print coverage. When newspaper coverage is at its lowest, the difference between low- and higheducation respondents is modest (8 percentage points). The gap in knowledge between these groups grows nearly

\footnotetext{
${ }^{25}$ We get similar results when we use alternate measures, such as the sum of news stories across our print and broadcast sources and the sum of news stories across all three sources. Our conclusions also remain the same when we used a logged measure of media coverage.

${ }^{26}$ We computed predicted probabilities using means for continuous variables and modal values for dichotomous variables. Low education corresponds to a person with a high school diploma; high education corresponds to a person with schooling after college. We use the sample minimum and maximum for the environmentallevel variables.
}

\section{FIGURE 4 The Effects of the Information Environment on the Relationship between Education and Knowledge}

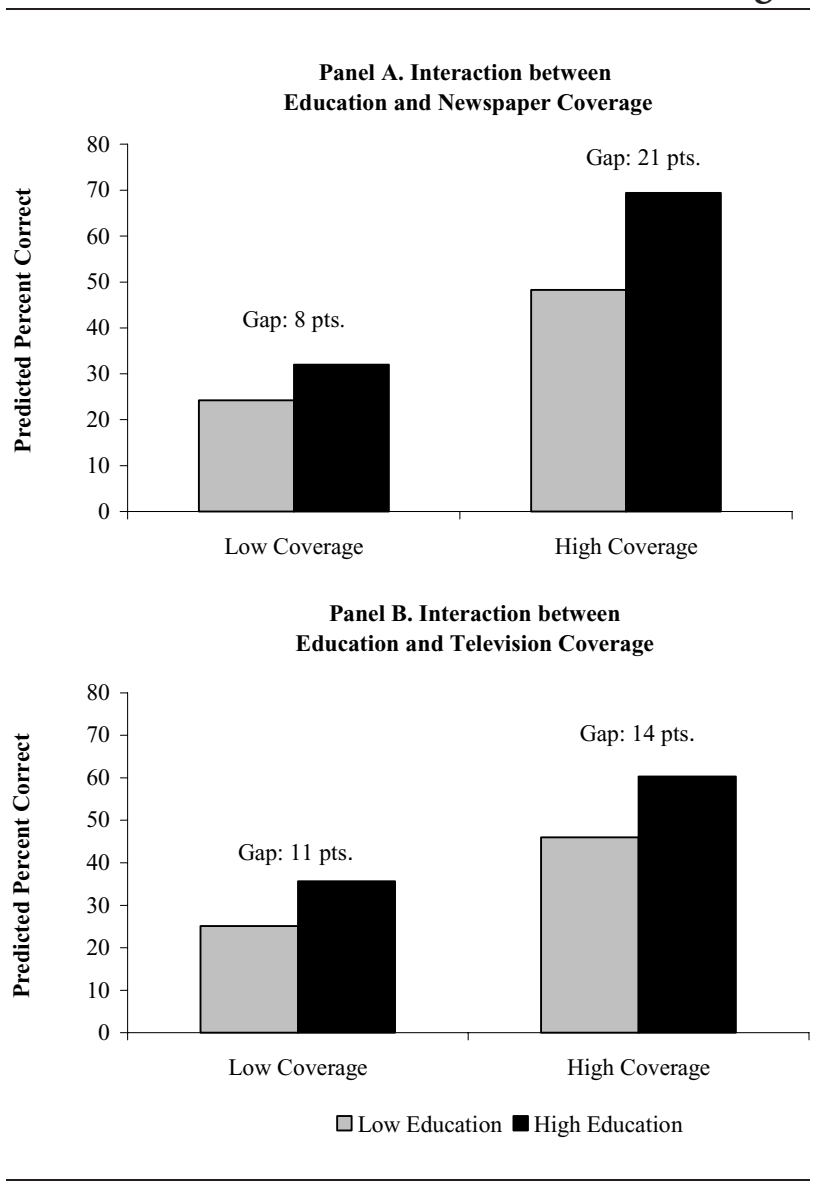

three-fold (21 percentage points) when print coverage is abundant. Underlying this growth are differential rates of learning. Low education respondents are 24 percentage points more likely to get the correct answer when newspaper coverage is at its maximum (the difference between 24 and 48); high-education respondents, by contrast, are nearly 40 percentage points more likely to get the correct answer (the difference between 32 and 69).

Panel B displays the comparison between low- and high-education groups across different levels of television coverage. While it is true that the gap between low- and high-education respondents increases along with the volume of television coverage, the difference is small and statistically insignificant. ${ }^{27}$ The subtle effect of television can be seen by comparing the increase in predicted percent correct across the two groups. Contrary to the preceding panel, low-education respondents benefit nearly as much

\footnotetext{
${ }^{27}$ The coefficient on Education X television is indistinguishable from zero (Table 1).
} 
from an increase in television coverage as high-education respondents. They are 21 percentage points more likely to get the correct answer when television coverage is at its maximum (the difference between 25 and 46); higheducation respondents are 24 percentage points more likely to get the correct answer (the difference between 36 and 60). Relative to the starting point for each group, this translates into a $84 \%$ gain for the least educated but only a $67 \%$ gain for the most educated. ${ }^{28}$ As others have noted, television may have little to offer the most educated beyond what they already know (Eveland and Scheufele 2000). Finally, although it is not our central focus, respondents do worse on more difficult items. The negative sign on Education $X$ difficulty suggests that the relationship between education and knowledge diminishes on more difficult questions.

The motivation for our multilevel model was the fact that we expected to observe, and indeed found evidence of, random variation in our parameters. A common way of assessing the explanatory power of a multilevel model is to calculate the proportion of the variance explained in the parameters as one goes from a random coefficients model without any level-two predictors to one that includes measures of volume and difficulty. Accounting for the volume of print and television coverage reduces the variance in the intercept coefficient by nearly $60 \%$; it reduces the variance in the education coefficient by $41 \% .{ }^{29}$ Thus, not only were we able to account for sizable variation in the average level of knowledge across our 41 surveys, but we also made significant headway in understanding how the effect of education varies with changes in the information environment. The fact that the variance components for the intercept and education parameter remain significant (Table 1) indicates that other environmentallevel factors might further reduce the variance of these parameters.

\footnotetext{
${ }^{28}$ Freedman, Franz, and Goldstein $(2004,733-34)$ come to similar conclusions regarding the impact of television ads on candidate knowledge. They find no evidence of differential effects (i.e., low information citizens do not learn significantly more from ads than high-information respondents), but the relative increase in knowledge for the least informed is large compared to the highly informed.

${ }^{29}$ These figures were calculated by comparing the variance components from random intercept and coefficients models with those for the fully specified models of Table 1. For example, the percent reduction in variance for the intercept is equal to:
}

$$
\frac{\tau_{00}(\text { RandomIntercept })-\tau_{00}(\text { Full })}{\tau_{00}(\text { RandomIntercept })}
$$

\section{Discussion}

Our analysis has shown that the relationship between education and knowledge varies along with changes in the information environment (see Kuklinski et al. 2001, 42122 , for a related finding). Increases in newspaper coverage primarily benefit the highly educated, thereby reinforcing the relationship between education and knowledge (Figure 4a). By contrast, increases in the volume of television coverage benefit the least educated, in absolute terms, almost as much as the most educated (Figure $4 \mathrm{~b}$ ). Additional content analyses highlight some of the differences between print and broadcast news and shed further light on our findings.

For each of the issues in our sample, we tallied the number of experts that were quoted or paraphrased in media reports. We also coded each story according to its level of contextual coverage. As the name implies, contextual coverage refers to any kind of reporting that discusses the historical, political, or social background of an issue (Bennett 2003; Graber 2004). This includes articles that consider why a particular policy action has been taken, that discuss the consequences of a policy change, or that provide an in-depth discussion of an issue or problem. Expert commentary and contextual coverage typically are considered indicators of quality in news reporting, however, citizens with low education seem the least able to digest this type of information. Separate analyses show that our print source (USA Today) was significantly more likely to provide contextual coverage than our broadcast source (CBS Evening News); there was, however, no significant difference in the level of expert commentary across print and television news. ${ }^{30}$ Thus, differences in the amount of contextual coverage in newspapers and television, combined with differential rates of learning, contribute to the patterns found in Table 1 (see Kleinnijenhuis 1991, 520, for a similar conclusion).

Although our findings are robust to alternative specifications, several issues give us pause. First, there is the potential problem of selection in the newspaper versus television model (Table 1). Given the abstract writing style of many newspapers, individuals with low levels of education might be more likely to choose television as their main source of political information. If so, estimates of the knowledge gap between education groups could be biased. Fortunately, in 11 of the 41 surveys, respondents were asked where they got most of their information. The

\footnotetext{
${ }^{30} \mathrm{~T}$-tests for the differences in proportions are as follows: $t_{\text {context }}=$ $-2.345 ; \mathrm{p}<.05$ and $t_{\text {expert }}=.784 ; \mathrm{p}<.44$.
} 
choices were television, newspapers, radio, magazines, the internet, friends, or other sources. We reestimated the models in Table 1 on the smaller dataset and reproduced the same pattern of findings. We then included the media use variables in the model to control for the possibility that high- and low-education groups rely on different media sources. With the exception of the indicator for friends, which was negatively related to knowledge ( $\mathrm{p}<.05)$, these dummy variables were not significant, nor did their inclusion alter any of our substantive conclusions. $^{31}$

Another concern is that there may be patterns in the types of issues which receive media attention (i.e., media coverage is not exogenous). Two types of issues stand out in this regard. First, we might expect to observe differences in coverage for partisan and nonpartisan issues. Partisan issues often are, or have a history of being, highly contested. The ease with which these issues can be presented in news stories, and the presence of two readily identifiable "sides," might make them a favored topic among members of the media. If so, we would expect there to be a greater number of news stories on partisan issues. Second, a number of our cases have to do with presidential initiatives or major statements of administration policy (e.g., the State of Union Address). Given the role of the president as a central protagonist in news stories, we might expect that relative to the other issues in our dataset, the number of stories will be higher when the topic is a presidential initiative. Fortunately, $t$-tests show no significant differences in the volume of coverage across our three sources for either partisan issues or presidential initiatives ( $p$ values range from .17 to .77). Thus, while media coverage may not be entirely exogenous - production values drive coverage to some extent-we did not uncover any relationship between the issues we examined here and the volume of news stories across any of our sources.

Finally, many of the surveillance issues in this study are public health topics. To the extent our sample of issues is biased, this threatens the generalizability of our results (i.e., "health knowledge" as opposed to knowledge); it also could violate the assumption that the $j$-units are sampled randomly. In separate analyses, we sought to determine if issue type was significantly related to the variation in the parameters. In the aggregate, citizens are more knowledgeable about health issues $(\mathrm{p}<.10)$. However, this variable did not moderate the impact of education nor did it alter the findings we report in Table 1.

\footnotetext{
${ }^{31}$ See Prior (2005) for a discussion of the effect of media choice on knowledge.
}

\section{Conclusion}

Higher levels of political knowledge have been associated with an impressive range of outcomes: more tolerance, greater levels of participation, and an increased ability to assimilate information, just to name a few (e.g., Delli Carpini and Keeter 1996; Krosnick and Brannon 1993; Rahn, Aldrich, and Borgida 1994). To the extent that the most knowledgeable are more likely to make decisions consistent with their interests and values, the distribution of knowledge bears directly upon the quality of representation (Althaus 2003; Converse 1990). Thus we agree with Eveland and Scheufele who state, "when there are disparities across social groups in political knowledge ... democracy is at least a little less democratic, regardless of the underlying reason for these inequities" (2000, 216).

We examined whether variation in the amount of media coverage exacerbates the disparities between the information haves and have-nots. Differences in knowledge that have been attributed to education become greater in environments in which information is plentiful. This is particularly the case with print news, which is more abstract and factual, with few visual aids. Increases in television coverage do not lead to a significant increase in the knowledge gap between lowand high-education groups. Indeed, our results show that the least educated benefit nearly as much as the most educated (and in terms of relative gains, they do better).

Our findings have important implications for scholars, journalists, and political leaders. Simply providing more information is likely to reinforce the knowledge gap that exists between people with low and high levels of education. Although scholars lament the tendency of television to provide "simplistic, nonsubstantive, nonhistorical and noncontextual" coverage (Postman 1985, 141; also see Bennett 2003), our results suggest the importance of transmitting political information in ways that can be comprehended by the least educated. This conclusion is supported by others who have noted that the least educated gravitate to easily digestible formats such as TV news (e.g., Neuman, Just, and Crigler 1992) and the efficiency with which they learn from television (Chaffee and Frank 1996; Kleinnijenhuis 1991). Even if learning from this medium is largely passive or unintentional (e.g., Zukin and Snyder 1984), individuals may obtain enough information to function as monitorial citizens (Schudson 1998).

This study represents an initial step toward a better understanding of how media coverage affects citizen 
knowledge. However, as our own analysis suggests, we have yet to account for all the variation in the educationknowledge relationship. It stands to reason, then, that other features of the information environment (e.g., how the news is packaged, not just its sheer amount) might affect the size and presence of knowledge gaps. The question of whether the information environment affects the relationship between knowledge and other demographic characteristics (e.g., race, gender) also remains open. Thus, while decades of research at the individual-level may have led to pessimistic conclusions regarding the distribution of knowledge, greater attention to the information environment might cast those conclusions in a different light.

\section{TABLE A1 Political Knowledge Questions and Answers}

\begin{tabular}{|c|c|c|}
\hline Question & Answer & Survey Period \\
\hline Can states restrict abortion in the first trimester? & They can after Casey decision & April 30-May 3, 1992 \\
\hline Clinton's policy on gays in the military & Don't ask, don't tell & July 29-August 1, 1993 \\
\hline Clinton administration health care plan & Workers guaranteed coverage & December 2-5, 1993 \\
\hline How many killed in Rawanda massacre? & Approximately 250,000 killed & May $12-15,1994$ \\
\hline U.S. intervention in Haiti & American forces killed Haitians & October 6-10, 1994 \\
\hline California Proposition 215 on marijuana & Allowed use in medical situations & December 13-17, 1996 \\
\hline FDA action on allergy drug Seldane & Steps to remove Seldane from shelves & February 22-24, 1997 \\
\hline Balance budget agreement and Medicare & Proposal to increase Medicare premiums & June 18-22, 1997 \\
\hline Congressional proposals on Medicare & Require upper income seniors to pay more & August 7-10, 1997 \\
\hline Size of budget deficit relative to five years prior & Decreased & August 7-10, 1997 \\
\hline Why was Phen-Fen taken off the market? & It caused heart valve problems & October 17-21, 1997 \\
\hline Bombing of abortion clinic in Alabama & Someone was killed & February 13-17, 1998 \\
\hline Main reason for reforms of Social Security & Projected funding problems in $30 \mathrm{yrs}$. & April 17-27, 1998 \\
\hline Insurance coverage for Viagra versus birth control & Companies more likely to cover Viagra & June $12-18,1998$ \\
\hline Congressional action on patients' rights legislation & Congress has yet to take any action & August 6-20, 1998 \\
\hline How does Preven work? & Prevents a pregnancy from occurring & October $10-18,1998$ \\
\hline Tobacco settlement & Right to sue not part of the settlement & December 8-13,1998 \\
\hline Clinton proposals on Social Security & Government investment in stocks & February 19-25, 1999 \\
\hline Report on financial condition of Social Security & Run out of money later than expected & April 10-22, 1999 \\
\hline Pharmaceutical companies and price fixing & Pled guilty to vitamin price fixing & June 11-16, 1999 \\
\hline Has patients' rights been voted on by the Senate? & It was passed in the Senate & August 6-10, 1999 \\
\hline Nat'l Academy of Sciences on hospital errors & New gov't agency to protect patients & December 3-13, 1999 \\
\hline Clinton State of the Union Address 2000 & Proposed lowering Medicare to age 55 & February $4-8,2000$ \\
\hline President Clinton and gun control & Called for background checks at shows & March 31-April 3, 2000 \\
\hline Democratic proposals for Medicare drug coverage & Proposed to pay for prescription drugs & May 26-June 4, 2000 \\
\hline Supreme Court action on partial-birth abortion & States do not have right to outlaw & August 2-6, 2000 \\
\hline Employer premiums for health insurance & Increased faster than in previous years & Sept. 29-Oct.2, 2000 \\
\hline FDA warning about PPA in medications & Cold and cough medicines & Nov. 29-Dec.3, 2000 \\
\hline Cabinet nomination of Tommy Thompson & Nominated for Secretary of Dept. of HHS & January $25-28,2001$ \\
\hline Solvency of Medicare and Social Security & Government reports more longevity & March 28-April 1, 2001 \\
\hline Senate action on the McCain-Feingold bill & Senate passed the bill & April 18-22, 2001 \\
\hline Patients' rights legislation & Patients can sue health plans & May 31-June 3, 2001 \\
\hline Why controversy on funding stem cell research? & Human embryos are destroyed & August 2-5, 2001 \\
\hline Why injunction against Bush plan for drug cards? & A lawsuit filed by drugstore chains & Sept. 28-Oct. 1, 2001 \\
\hline Action on prescription drug discount cards & Private company creates card program & Jan. 31-Feb. 3, 2002 \\
\hline Action to provide elderly relief on prescription drugs & Pharmacies establish drug card program & March 28-31, 2002 \\
\hline International AIDS conference statements & Prevention programs are effective & July $18-21,2002$ \\
\hline How is West Nile Virus spread? & Carried by mosquitoes & Oct. $10-13,2002$ \\
\hline Risk factors associated with cervical cancer & $\mathrm{HPV}$ is associated with cervical cancer & December 6-10, 2002 \\
\hline President Bush's proposal for fighting AIDS & Increase U.S. funding for AIDS in Africa & February 6-10, 2003 \\
\hline Senate action on partial-birth abortion ban & Voted to pass the bill & April 3-6, 2003 \\
\hline
\end{tabular}

Note: Complete question wording, including response options, can be obtained from the Roper Center Archive. All surveys are separate cross-sections even though dates may overlap. 
TABle A2 Probit Estimates for Study 1

\begin{tabular}{|c|c|c|c|c|c|c|c|c|}
\hline \multicolumn{4}{|c|}{1998 Tobacco Settlement with States } & \multicolumn{5}{|c|}{1997 Congressional Proposals on Medicare } \\
\hline Parameter & $\begin{array}{l}\text { Right } \\
\text { to Sue }\end{array}$ & $\begin{array}{c}\text { Joe Camel } \\
\text { Ad Ban }\end{array}$ & $\begin{array}{c}\text { Payments } \\
\text { to States }\end{array}$ & $\begin{array}{c}\text { Means } \\
\text { Test Benefits }\end{array}$ & $\begin{array}{l}\text { Patient } \\
\text { Choice }\end{array}$ & $\begin{array}{c}\text { Cut } \\
\text { Provider Pay }\end{array}$ & $\begin{array}{c}\text { Raise Age } \\
\text { to } 67\end{array}$ & $\begin{array}{l}\text { Wealthy } \\
\text { Pay More }\end{array}$ \\
\hline Education & $\begin{array}{r}-0.001 \\
(0.027)\end{array}$ & $\begin{array}{c}0.043 \\
(0.028)\end{array}$ & $\begin{array}{c}0.097^{* *} \\
(0.029)\end{array}$ & $\begin{array}{c}0.006 \\
(0.044)\end{array}$ & $\begin{array}{c}-0.021 \\
(0.043)\end{array}$ & $\begin{array}{l}0.121^{* *} \\
(0.042)\end{array}$ & $\begin{array}{c}0.069+ \\
(0.041)\end{array}$ & $\begin{array}{c}0.086^{*} \\
(0.042)\end{array}$ \\
\hline Income & $\begin{array}{c}-0.056+ \\
(0.034)\end{array}$ & $\begin{array}{c}0.012 \\
(0.033)\end{array}$ & $\begin{array}{c}0.079 * \\
(0.034)\end{array}$ & $\begin{array}{r}-0.028 \\
(0.051)\end{array}$ & $\begin{array}{c}0.090+ \\
(0.050)\end{array}$ & $\begin{array}{c}0.041 \\
(0.051)\end{array}$ & $\begin{array}{r}-0.028 \\
(0.050)\end{array}$ & $\begin{array}{c}0.061 \\
(0.054)\end{array}$ \\
\hline Age & $\begin{array}{c}-0.002 \\
(0.003)\end{array}$ & $\begin{array}{c}0.005+ \\
(0.003)\end{array}$ & $\begin{array}{c}0.004 \\
(0.003)\end{array}$ & $\begin{array}{r}-0.001 \\
(0.004)\end{array}$ & $\begin{array}{c}0.001 \\
(0.004)\end{array}$ & $\begin{array}{r}-0.001 \\
(0.004)\end{array}$ & $\begin{array}{c}0.006 \\
(0.004)\end{array}$ & $\begin{array}{c}0.010^{* *} \\
(0.004)\end{array}$ \\
\hline Female & $\begin{array}{r}-0.076 \\
(0.085)\end{array}$ & $\begin{array}{r}-0.085 \\
(0.086)\end{array}$ & $\begin{array}{c}-0.312^{* *} \\
(0.088)\end{array}$ & $\begin{array}{r}-0.140 \\
(0.126)\end{array}$ & $\begin{array}{c}-0.184 \\
(0.122)\end{array}$ & $\begin{array}{r}-0.158 \\
(0.125)\end{array}$ & $\begin{array}{c}0.037 \\
(0.123)\end{array}$ & $\begin{array}{r}-0.145 \\
(0.128)\end{array}$ \\
\hline Black & $\begin{array}{r}-0.050 \\
(0.145)\end{array}$ & $\begin{array}{r}-0.093 \\
(0.142)\end{array}$ & $\begin{array}{c}-0.002 \\
(0.148)\end{array}$ & $\begin{array}{c}0.094 \\
(0.198)\end{array}$ & $\begin{array}{c}-0.098 \\
(0.203)\end{array}$ & $\begin{array}{r}-0.017 \\
(0.207)\end{array}$ & $\begin{array}{r}-0.247 \\
(0.200)\end{array}$ & $\begin{array}{c}0.044 \\
(0.216)\end{array}$ \\
\hline Follows issue & $\begin{array}{c}0.133^{* *} \\
(0.045)\end{array}$ & $\begin{array}{c}0.301^{* *} \\
(0.043)\end{array}$ & $\begin{array}{c}0.360^{* *} \\
(0.045)\end{array}$ & $\begin{array}{c}0.168^{* *} \\
(0.061)\end{array}$ & $\begin{array}{c}0.095 \\
(0.058)\end{array}$ & $\begin{array}{c}0.248^{* *} \\
(0.061)\end{array}$ & $\begin{array}{c}0.144^{* *} \\
(0.059)\end{array}$ & $\begin{array}{c}0.247^{* *} \\
(0.061)\end{array}$ \\
\hline Constant & $\begin{array}{c}-0.711^{* *} \\
(0.232)\end{array}$ & $\begin{array}{r}-0.520^{*} \\
(0.227)\end{array}$ & $\begin{array}{c}-1.144^{* *} \\
(0.238)\end{array}$ & $\begin{array}{c}-0.583+ \\
(0.332)\end{array}$ & $\begin{array}{c}-0.493 \\
(0.310)\end{array}$ & $\begin{array}{c}-1.294^{* *} \\
(0.309)\end{array}$ & $\begin{array}{r}-0.665^{*} \\
(0.316)\end{array}$ & $\begin{array}{c}-1.273^{* *} \\
(0.347)\end{array}$ \\
\hline$N$ & 1,201 & 1,201 & 1,201 & 494 & 494 & 494 & 494 & 494 \\
\hline
\end{tabular}

Note: Table entries are multivariate probit maximum likelihood estimates with robust standard errors in parentheses. Rho coefficients have been suppressed for presentation purposes. The data have been weighted to reflect the U.S.

\section{Appendix}

\section{The Political Knowledge Series}

When constructing the political knowledge series, we looked for surveys conducted by a single organization which contained questions about political knowledge and news attention. A search of all available dates in the Roper Center for Public Opinion Research iPoll database turned up 41 surveys conducted by Princeton Survey Research Associates that had at least one close-ended political knowledge question as well as a measure of how closely the respondent was following that issue. Most of the 41 surveys we chose had more than one knowledge question, in which case we randomly selected a question. ${ }^{32}$ Table A1 lists the question topic and correct answer for each of the surveys we use in the analysis.

Detailed information on the surveys, including question wording, order, and introductions, etc., is available at the Roper Center. The Kaiser Family Foundation and Harvard School of Public Health sponsored many of the surveys in our sample. For more information on survey methodology and response rates, see Brodie et al. (2003) or http://www.kkf.org.

\footnotetext{
${ }^{32}$ Study 2 has two randomly selected questions from Study 1 (right to sue, wealthy pay more).
}

\section{Study 1 Probit Coefficients}

Table A2 presents the coefficients for the models described in Study 1 (Figure 1). Question wording is available at the Roper Center.

\section{References}

Althaus, Scott L. 2003. Collective Preferences in Democratic Politics: Opinion Surveys and the Will of the People. Cambridge: Cambridge University Press.

Alvarez, R. Michael. 1997. Information and Elections. Ann Arbor: Univ. of Michigan Press.

Bennett, Lance. 2003. News: The Politics of Illusion, $5^{\text {th }}$ ed. White Plains: Longman.

Bennett, Stephen E. 1988. “'Know-Nothings' Revisited: The Meaning of Political Ignorance Today.” Social Science Quarterly 69(June):476-90.

Brians, Craig L., and Martin P. Wattenberg. 1996. "Campaign Issue Knowledge and Salience: Comparing Reception from TV Commercials, TV News, and Newspapers." American Journal of Political Science 40(February):172-93.

Brodie, Molly Ann, Elizabeth C. Hamel, Drew E. Altman, Robert J. Blendon, and John M. Benson. 2003. "Health News and the American Public, 1996-2002." Journal of Health Politics, Policy and Law 28(October):927-50.

Chaffee, Steven, and Stacey Frank. 1996. "How Americans Get Political Information: Print versus Broadcast News.” 
Annals of the American Academy of Political and Social Sciences 546(July):48-58.

Cicchetti, Domenic, and Sara S. Sparrow. 1981. "Developing Criteria for Establishing Interrater Reliability of Specific Items: Applications to Assessment of Adaptive Behavior." American Journal of Mental Deficiency 86(2):127-37.

Converse, Philip E. 1990. "Popular Representation and the Distribution of Information." In Information and Democratic Processes, ed. John A. Ferejohn and James H. Kuklinski. Urbana: University of Illinois Press, pp. 369-88.

Dalton, Russell Paul, A. Beck, and Robert Huckfeldt. 1998. "Partisan Cues and the Media: Information Flows in the 1992 Presidential Election." American Political Science Review 92(March):111-26.

Delli Carpini, Michael X., and Scott Keeter. 1991. "Stability and Change in the U.S. Public's Knowledge of Politics.” Public Opinion Quarterly 55(Winter):583-612.

Delli Carpini, Michael X., and Scott Keeter. 1996. What Americans Know About Politics and Why It Matters. New Haven: Yale University Press.

Delli Carpini, Michael X., Scott Keeter, and J. David Kennamer. 1994. "Effects of the News Media Environment on Citizen Knowledge of State Politics and Government." Journalism Quarterly 71(2):443-56.

Druckman, James N. 2005. "Media Matter: How Newspapers and Television News Cover Campaigns and Influence Voters." Political Communication 22(October-December):46381.

Eveland, William P., and Dietram A. Scheufele. 2000. "Connecting News Media Use with Gaps in Knowledge and Participation.” Political Communication 17(July):215-37.

Freedman, Paul, Michael Franz, and Kenneth Goldstein. 2004. "Campaign Advertising and Democratic Citizenship." American Journal of Political Science 48(October):723-41.

Gaziano, Cecilie. 1983. "The Knowledge Gap: An Analytical Review of Media Effects." Communication Research 10(October):447-86.

Gaziano, Cecilie. 1997. "Forecast 2000: Widening Knowledge Gaps.” Journal of Mass Communication Quarterly 74(2):23764.

Gilens, Martin. 2001. "Political Ignorance and Collective Policy Preferences." American Political Science Review 95(June):379-96.

Goldstein, Harvey. 2003. Multilevel Statistical Models, $3^{\text {rd }}$ ed. London: Arnold.

Gordon, Stacy B., and Gary M. Segura. 1997. "Cross-National Variation in the Political Sophistication of Individuals: Capability or Choice?" Journal of Politics 59(February):12647.

Graber, Doris A. 2004. "Mediated Politics and Citizenship in the Twenty-First Century." Annual Review of Psychology 55(January):545-71.

Graber, Doris A. 2002. Mass Media and American Politics, $6^{\text {th }}$ ed. Washington: Congressional Quarterly Press.

Graber, Doris A. 1994. "Why Voters Fail Information Tests: Can the Hurdles Be Overcome?" Political Communication 11(October-December):331-46.

Greene, William H. 2003. Econometric Analysis, $5^{\text {th }}$ ed. Upper Saddle River, NJ: Prentice Hall.
Hambleton, Ronald K., and Hariharan Swaminathan. 1985. Item Response Theory: Principles and Applications. Boston: Kluwer-Nijhoff Publishing.

Hetherington, Marc J. 1996. “The Media's Role in Forming Voters' National Economic Evaluations in 1992." American Journal of Political Science 40(May):372-95.

Holbrook, Thomas M. 2002. "Presidential Campaigns and the Knowledge Gap." Political Communication 19(October): 437-54.

Huckfeldt, Robert. 2001. "The Social Communication of Political Expertise." American Journal of Political Science 45(April):425-38.

Hutchings, Vincent. 2001. "Political Context, Issue Salience, and Selective Attentiveness: Constituent Knowledge of the Clarence Thomas Confirmation Vote." Journal of Politics 63(August):846-68.

Hutchings, Vincent L. 2003. Public Opinion and Democratic Accountability. Princeton: Princeton University Press.

Iyengar, Shanto. 1990. "Shortcuts to Political Knowledge: The Role of Selective Attention and Accessibility." In Information and Democratic Processes, eds. John A. Ferejohn and James H. Kuklinski. Urbana: University of Illinois Press, pp. 160-85.

Just, Marion R., Ann N. Crigler, Dean E. Alger, Timothy E. Cook, Montague Kern, and Darrell M. West. 1996. Crosstalk: Citizens, Candidates and the Media in a Presidential Campaign. Chicago: University of Chicago Press.

King, Gary, James Honaker, Anne Joseph, and Kenneth Scheve. 2001. "Analyzing Incomplete Political Science Data." American Political Science Review 95(March):49-69.

Kleinnijenhuis, Jan. 1991. "Newspaper Complexity and the Knowledge Gap." European Journal of Communication 6(December):499-522.

Krassa, Michael A. 1990. "Political Information, Social Environments, and Deviants." Political Behavior 12(December):31530.

Krosnick, Jon A., and Laura A. Brannon. 1993. "The Impact of the Gulf War on the Ingredients of Presidential Evaluations: Multidimensional Effects of Political Involvement." American Political Science Review 87(December):963-75.

Kuklinski, James H., Paul J. Quirk, Jennifer Jerit, and Robert F. Rich. 2001. "The Political Environment and Citizen Competence." American Journal of Political Science 45(April):41024.

Kuklinski, James H., Paul J. Quirk, Jennifer Jerit, David Schwieder, and Robert F. Rich. 2000. "Misinformation and the Currency of Citizenship." Journal of Politics 62(August):791-816.

Kwak, Nojin. 1999. "Revisiting the Knowledge Gap Hypothesis: Education, Motivation, and Media Use." Communication Research 26(August):385-413.

Leighley, Jan E. 2004. Mass Media and Politics: A Social Science Perspective. New York: Houghton Mifflin Company.

Lodge, Milton, Marco R. Steenbergen, and Shawn Brau. 1995. "The Responsive Voter: Campaign Information and the Dynamics of Candidate Evaluation." American Political Science Review 89(June):309-26.

Lord, Frederic M., and Melvin R. Novick. 1968. Statistical Theories of Mental Test Scores. Reading, MA: AddisonWesley. 
Lupia, Arthur, and Mathew D. McCubbins. 1998. The Democratic Dilemma. Cambridge: Cambridge University Press.

Luskin, Robert C. 1990. "Explaining Political Sophistication." Political Behavior 12(December):331-61.

Luskin, Robert C., and John Bullock. 2005. “Don't Know Means Don't Know." Paper presented at the Annual Meeting of the Midwest Political Science Association.

McLeod, Jack M., Carl R. Bybee, and Jean A. Durall. 1979. "Equivalence of Informed Political Participation: The 1976 Debates as Source of Information." Communication Research 6(October):463-87.

Miyo, Yuko. 1983. "The Knowledge-Gap Hypothesis and Media Dependency." In Communication Yearbook, Part 7, ed. Robert N. Bostrom. London: Sage, pp. 626-50.

Mondak, Jeffery J. 2001. "Developing Valid Knowledge Scales.” American Journal of Political Science 45(January):22438.

Mutz, Diana C., and Jeffrey J. Mondak. 2006. "The Workplace as a Context of Cross-Cutting Political Discourse.” Journal of Politics 68(February):140-55.

Neuman, W. Russell. 1986. The Paradox of Mass Politics: Knowledge and Opinion in the American Electorate. Cambridge: Harvard University Press.

Neuman, W. Russell, Marion R. Just, and Ann N. Crigler. 1992. Common Knowledge: News and the Construction of Political Meaning. Chicago: University of Chicago Press.

Nicholson, Stephen P. 2003. "The Political Environment and Ballot Proposition Awareness." American Journal of Political Science 41(July):403-10.

Pinheiro, Jose C., and Douglas M. Bates. 2000. Mixed-Effects Models in S and S-PLUS. New York: Springer.

Postman, Neil. 1985. Amusing Ourselves to Death: Public Discourse in the Age of Show Business. New York: Penguin.

Price, Vincent, and Edward J. Czilli. 1996. "Modeling Patterns of News Recognition and Recall." Journal of Communication 46(Spring):55-78.

Price, Vincent, and John Zaller. 1993. "Who Gets the News? Alternative Measures of News Reception and Their Implications for Research.” Public Opinion Quarterly 57(Summer):133-64.
Prior, Markus. 2005. "News vs. Entertainment: How Increasing Media Choice Widens Gaps in Political Knowledge and Turnout." American Journal of Political Science 49(July):577_ 92.

Rahn, Wendy, Aldrich John, and Borgida Eugene. 1994. "Individual and Contextual Variations in Political Candidate Appraisal." American Political Science Review 88(March):19399.

Rasbash, Jon, William Browne, Harvey Goldstein, Min Yang, Ian Plewis, Michael Healy, Geoff Woodhouse, David Draper, Ian Langford, and Toby Lewis. 2000. "A User's Guide to MLwiN." London: Multilevel Models Project at the Institute of Education, University of London.

Raudenbush, Stephen W., and Anthony S. Bryk. 2002. Hierarchical Linear Models: Applications and Data Analysis Methods, $2^{\text {nd }}$ ed. Newbury Park: Sage.

Rhine, Staci L., Stephen Earl Bennett, and Richard S. Flickinger. 2001. "Gaps in Americans' Knowledge about the Bosnian Civil War." American Politics Research 29(November):592607.

Robinson, John P., and Mark R. Levy. 1986. The Main Source: Learning from Television News. Beverly Hills: Sage.

Schudson, Michael. 1998. The Good Citizen: A History of American Public Life. New York: Free Press.

Smith, Mark A. 2002. "Ballot Initiatives and the Democratic Citizen.” Journal of Politics 64(August):892-903.

Steenbergen, Marco R., and Bradford S. Jones. 2002. "Modeling Multilevel Data Structures." American Journal of Political Science 46(January):218-37.

Tichenor, Philip J., George A. Donohue, and Calice N. Olien. 1970. "Mass Media Flow and Differential Growth in Knowledge.” Public Opinion Quarterly 34(Summer):159-70.

Zaller, John. 1992. The Nature and Origins of Mass Opinion. Cambridge: Cambridge University Press.

Zaller, John. 2003. “A New Standard of News Quality: Burglar Alarms for the Monitorial Citizen." Political Communication 20(April-June):109-30.

Zukin, Cliff, and Robin Snyder. 1984. "Passive Learning: When the Media Environment Is the Message." Public Opinion Quarterly 48(Autumn):629-38. 